\title{
Assessment of Oxidative Stress by Trace Elements in Pregnant Kankrej Cows
}

\author{
Jinnal Patel*, Sandhya S. Chaudhary, Abid Dadawala and Vishal Patel \\ Department of Animal Physiology \& Biochemistry, College of Veterinary Science \\ \& Animal Husbandry, Sardarkrushinagar Dantiwada Agricultural University, \\ Sardarkrushinagar-385 506, Gujarat, India \\ *Corresponding author
}

\begin{tabular}{l} 
Ke y w o r d s \\
Antioxidant trace \\
elements, Copper, \\
Iron, Oxidative \\
stress, pregnant \\
Kankrej cow, Zinc \\
\hline Article Info \\
\hline $\begin{array}{l}\text { Accepted: } \\
\text { 20 February } 2020 \\
\text { Available Online: } \\
\text { 10 March } 2020\end{array}$ \\
\hline
\end{tabular}

\section{A B S T R A C T}

The present study was carried out with the objectives to study oxidative stress in periparturient cows by estimation of the levels of antioxidant trace elements copper, zinc and iron in plasma at 30, 15 days before parturition, on the day of parturition, 15 and 30 days after parturition. During study significantly higher levels of zinc $(\mathrm{P}<0.05)$ and iron $(\mathrm{P}<0.01)$ was observed between control and parturited animals. This indicates higher oxidative stress on the day of parturition. Zinc and iron decreased significantly from 30 days before parturition and attained lowest levels on the day of parturition. However, the level increased gradually thereafter up to 30 days after parturition. Significant increase in copper level was observed on the day of parturition, thereafter the levels decreased. Copper is a constituent of SOD enzyme and levels of SOD also increased on the day of parturition. The present study indicates some kind of role of the antioxidant trace elements, zinc and iron in protecting cows from oxidative stress as their levels significantly decreased during pregnancy and parturition.

\section{Introduction}

A living creature has to survive under the environment created as a result of interactions of internal and external factors. There are many physiological processes namely parturition, milk production, preterm labor, lactation which create a stressful condition in the animal body. As it is very well known that during the various biochemical metabolic processes nascent oxygen is released and its level is regulated by various antioxidative agents of the body.

Deficiency of any such antioxidative agent will favour the prevailing of the nascent oxygen which will be damaging the cell's metabolic processes or cell itself and produce 
reactive oxygen species (ROS), such as hydroxyl radicals, superoxide anion, and hydrogen peroxides. The balance between the rate at which oxidative damage is induced (input) and the rate at which it is efficiently repaired and removed (output) determines the level of oxidative stress. The rate at which damage is caused is determined by how fast the ROS are generated and then inactivated by endogenous defense agents called antioxidants. In a healthy animal, ROS and antioxidants remain in balance, when the balance is disrupted towards an over abundance of ROS, oxidative stress occurs.

Oxidative stress can also lead to the modification of important physiological and metabolic functions. This damage can affect a specific molecule or the entire organism and leads to peroxidative damage of lipids and other macromolecules, with consequent alteration of cell membranes and other cellular components (Toyokuni, 1999).

Trace minerals, such as iron (in catalase), copper, zinc, manganese (in superoxide dismutase) and selenium (in glutathione peroxidase), are essential to the structure and function of many of these antioxidant enzymes (Kleczkowski et al., 2003).

Oxidative stress plays a role in multiple physiological processes from oocyte maturation to fertilization, embryo development during pregnancy, in normal parturition and in initiation of preterm labor (Agrawal et al., 2005).

Pregnancy is a physiological state accompanied by a high energy demand for many bodily functions and an increased oxygen requirement. Because of the increased intake and utilization of oxygen augmented level of oxidative stress would be expected (Gitto et al., 2002). Looking to the immense importance of trace elements in pregnancy we determined the level of endogenous antioxidant minerals viz. zinc, copper and iron in plasma of pre and post parturient cows.

\section{Materials and Methods}

The present study was carried out in Department of Animal Physiology and Biochemistry and in collaboration with Department of Animal Nutrition, College of Veterinary Science and Animal Husbandry, Sardarkrushinagar Dantiwada Agricultural University, Sardarkrushinagar. The samples from twelve healthy Kankrej cows were taken from Livestock Research Station, Sardarkrushinagar Dantiwada Agricultural University, Sardarkrushinagar. The animals were kept under loose system of housing, in well-ventilated hygienic sheds and fed on standard ration including green fodder. Twelve animals were divided into two groups of six animals each.

Group-I (control group) comprised of six healthy non-pregnant Kankrej cows in their second or third lactation.

Group-II (experimental or periparturient group) comprised of six periparturient Kankrej cows.

Approximately $10 \mathrm{ml}$ of blood was collected aseptically in heparinized vials by puncturing the jugular vein of animals under study. Blood was collected only once at diestrous stage from Group I animals. Blood samples were collected at approximately 30, 15 days before parturition, on the day of parturition, 15 and 30 days after parturition from Group II animals. The plasma samples were separated from whole blood by centrifugation at 3000 rpm for 15 minutes, and stored at $-20^{\circ} \mathrm{C}$ for further analysis. Biochemical analyses of plasma samples were carried out for trace elements. 


\section{Trace elements}

$0.2 \mathrm{ml}$ of blood plasma samples were digested with $1.8 \mathrm{ml}$ of triple acid mixture (concentrated sulphuric acid: perchloric acid: nitric acid in the ratio of 1:2:1) till it becomes colorless. After digestion the final volume was made to $10 \mathrm{ml}$ with triple glass distilled water. Copper, zinc and iron concentration from the digested samples were determined by atomic absorption spectrophotometer (Model AAS 4141, Electronic Corporation of India Ltd. make) method as described by (Oser, 1979).

\section{Statistical analysis}

The significance of difference between means for different biochemical parameters were tested by applying paired t-test for dependant samples and unpaired t-test for independent samples assuming equal variances (Snedecor and Cochran, 1994).

\section{Results and Discussion}

\section{Zinc}

\section{Control group with periparturient group}

The mean concentration of zinc in blood plasma of non-pregnant Kankrej cows was $1.24 \pm 0.02 \mathrm{ppm}$, while that in periparturient cows at 30 and 15 days before parturition, on the day of parturition, 15 and 30 days after parturition were $1.06 \pm 0.06,1.05 \pm 0.07$, $1.02 \pm 0.071 .19 \pm 0.07$ and $1.23 \pm 0.06 \mathrm{ppm}$, respectively and the same has been presented in Table.

\section{Periparturient group}

The results indicate that the plasma zinc concentration was significantly lowest on the day of parturition $(1.02 \pm 0.07 \quad \mathrm{ppm})$ compared to 30 and 15 days before parturition, 15 and 30 days after parturition $(1.06 \pm 0.06,1.05 \pm 0.07,1.19 \pm 0.07$ and $1.23 \pm 0.06 \mathrm{ppm}$, respectively) of the experiment. A decreasing trend in levels was observed from 30 day before parturition, while reverse trend was observed after the day of parturition.

\section{Copper}

\section{Control group with periparturient group}

Copper concentration in blood plasma of nonpregnant Kankrej cows was observed to be $1.19 \pm 0.01 \mathrm{ppm}$, and the same has been presented in Table.

Highly significant differences $(\mathrm{p}<0.01)$ were observed for copper level between nonpregnant group with periparturient group at 30,15 day prepartum and 30 day postpartum. Non-significant differences were observed between non- pregnant group with periparturient group on the day of parturition and 15 day after parturition.

\section{Periparturient group}

The result indicated that the plasma copper concentration was highly significantly higher on the day of parturition $(1.17 \pm 0.03 \mathrm{ppm})$ compared to 30 and 15 days before parturition, 15 and 30 days after parturition $(0.62 \pm 0.03,0.71 \pm 0.03,1.13 \pm 0.03$ and $0.82 \pm 0.03 \mathrm{ppm}$, respectively) of the experiment.

\section{Iron}

\section{Control group with periparturient group}

The average level of iron in blood plasma of non-pregnant Kankrej cows was $2.00 \pm 0.08$ ppm. The mean concentration of iron in blood plasma of control and periparturient group is given in Table. 


\section{Periparturient group}

The plasma iron concentration at 30,15 days before parturition, on the day of parturition, 15 and 30 day after parturition were $1.69 \pm$ $0.05,1.66 \pm 0.05,1.62 \pm 0.05,1.77 \pm 0.11$ and $1.99 \pm 0.10 \mathrm{ppm}$, respectively of the experiment.

Iron levels were lower in prepartum animals than postpartum. The lowest concentration of iron was observed on the day of parturition.

These micronutrients are cellular antioxidants, preventing peroxidative damage, in the cytoplasm (trace elements), and are essential for a well-functioning immune system (Weiss 2002). The variation observed in the blood content of minerals is largely in response to physiological changes that account during the periparturient period in dairy cows. Trace minerals, such as iron (in catalase), copper, zinc, manganese (in superoxide dismutase) and selenium (in glutathione peroxidase), are essential to the structure and function of many of the antioxidant enzymes (Kleczkowski et al., 2003) and reduces oxidative stress.

\section{Zinc}

\section{Control group with periparturient group}

Significantly higher level of zinc was found between non-pregnant cows and 15 day prepartum cows, between non-pregnant cows and recently parturited cows. On the day of parturition zinc levels were lowest. However non-significant differences were observed between non- pregnant group with 30 day prepartum, 15 and 30 day postpartum.

Zinc has a critical role in repair and maintenance of uterine lining following parturition and early return to normal reproductive function and oestrus. Zinc has also been shown to increase plasma betacarotene, which has been directly correlated to improved conception rate and early embryonic development. Our findings are in agreement with Pavlata et al., (2005), Akhtar et al., (2009), Cahit et al., (1999). However Dhami et al., (2003) found significantly lower zinc level in lactating animals than in cyclic and pregnant heifers. However, nonsignificant difference was observed for zinc level by Asif et al., (1996) and Gosai, N.M., (1998).

\section{Periparturient group}

Plasma zinc concentration was highly significantly lower on the day of parturition as compared different days of intervals during pre and post parturient period. There were highly significant differences $(\mathrm{p}<0.01)$ among all the five zinc levels measured on different days before and after parturition except significant differences were observed between 30 day before parturition with 15 day after parturition, 30 day before parturition with 30 day after parturition.

Similar results were observed by Dufty et al., (1977), Goff and Stable (1990), Meglia et al., (2001, 2004), Mehere et al., (2002), Jacob et al., (2003), Pankajkumar and Sharma (2005) and Ram Pravesh (2006). Non-significant difference was observed for zinc level by Asif et al., (1996). Cahit et al., (1999) found significantly higher concentration of zinc in early pregnant cows than in non-pregnant cows and concluded that zinc has an important role in early pregnancy in cows from the observed higher levels in early period of pregnant cows than non- pregnant cows.

Rapid need for zinc in synthesis of colostrum may explain why $\mathrm{Zn}$ concentration is $22 \%$ lower in blood of cows on day of calving (Kincaid, 2008). Zinc, is responsible for normal functions of certain antioxidant enzymes. The blood concentration of zinc decreased dramatically at calving mainly in 
response to colostrum formation (Goff and Stabel, 1990), and to redistribution to other tissues such as, liver.

The peripartum in dairy cows is considered a stressful period, and stress can induce synthesis of metallothionein, a protein associated with zinc metabolism, making zinc less available (Spears et al., 1991; Xin et al., 1993).

\section{Copper}

\section{Control group with periparturient group}

Highly significant differences $(p<0.01)$ were observed for copper level between nonpregnant group with periparturient group at 30, 15 day prepartum and 30 day postpartum. However, non-significant differences were observed between non- pregnant group with periparturient group on the day of parturition and 15 day after parturition.

Increased copper concentration during parturition may be required to trigger the endocrine glands related to the physiology of initiation of labor pain and process of parturition. Copper is an important cofactor of superoxide dismutase, an enzyme, which protects cells from the pro oxidative influence of free radicals (Kleczkowski, 2003).

Our findings are an agreement with Pavlata et al., (2005), Akhtar et al., (2009). However non-significant difference was reported by Asif et al., (1996), Gosai et al., (1999) and Cahit et al., (1999) for copper concentration. Dhami et al., (2003) found low copper in parturient and lactating cows compared to young calves, pregnant heifers and repeat breeding cows.

\section{Periparturient group}

Significantly higher level of plasma copper was found on the day of parturition as compared to 30, 15 days before parturition, 15 and 30 days after parturition. Copper is constituent of SOD enzyme and level of SOD also increased on the day of parturition.

Pregnancy is a copper dependant process and the body demands additional copper from conception onwards. Reduction in zinc and copper availability in the early postpartum period (Muehlenbein et al., 2001) of dairy cows might explain the reduction of SOD activity (Michiels et al., 1994). The level of copper during parturition was higher than pre parturition or early lactation. This might be due to conservation of copper by increasing absorption and preventing losses via excretory pathways in order to accommodate high demands of fetus. At parturition, increased circulatory levels of estrogen stimulate ceruloplasmin synthesis by the liver and thereby resulting in increased concentration of copper. Our finding were similar to those observed by Meglia et al., (2001), Mehere et al., (2002), Jacob et al., (2003). Pankajkumar and Sharma (2005), Asif et al., (1996), Cahit et al., (1999) and Ram Pravesh (2006) found non-significant difference for $\mathrm{Cu}$ level, contradictory to our findings. Devraj (1982) reported copper level was low up to 3 day postpartum which rose in subsequent stages.

\section{Iron}

\section{Control group with periparturient group}

The average level of iron in blood plasma of non-pregnant Kankrej cows was significantly higher than 30, 15 day pre-partum. Highly significant difference were observed between control animals and on the day of parturition, while non-significant differences were observed between non- pregnant group with 15 and 30 day post-partum group. Iron being an integral part of cytochrome oxidase/peroxidase and catalase enzymes, is responsible for biological oxidation. Our findings are an agreement with Akhtar et al., 
(2009), Setia et al., (1994). The nonsignificant difference was found by Asif et al., (1996), for iron concentration. The opposite result was observed by Dhami et al., (2003).

Table.1 Mean and standard error of zinc, copper and iron in blood plasma of Kankrej cows

\begin{tabular}{|c|c|c|c|c|}
\hline Group & Animal & Zinc (ppm) & Copper (ppm) & Iron (ppm) \\
\hline Group-I & $\begin{array}{l}\text { Non-pregnant } \\
\text { Kankrej cows } \\
\text { (Control) }\end{array}$ & $1.24 \pm 0.02^{1}$ & $1.19 \pm 0.01^{1}$ & $2.00 \pm 0.08^{1}$ \\
\hline Group-II & \multicolumn{4}{|l|}{ Peri parturient cows } \\
\hline 1. & $\begin{array}{l}30 \text { day before } \\
\text { parturition }\end{array}$ & $1.06 \pm 0.06^{1, a}$ & $0.62 \pm 0.03^{1 * *, a}$ & $1.69 \pm 0.05^{1 *, a}$ \\
\hline 2. & $\begin{array}{l}15 \text { day before } \\
\text { parturition }\end{array}$ & $1.05 \pm 0.07^{1 *, a^{* *}, b}$ & $0.71 \pm 0.03^{1^{* *}, a^{* *}, b}$ & $1.66 \pm 0.05^{1^{*}, a^{* *}, b}$ \\
\hline 3. & $\begin{array}{l}\text { On the day of } \\
\text { parturition }\end{array}$ & $1.02 \pm 0.07^{1^{*}, a^{* *}, b^{* *}, \mathrm{c}}$ & $1.17 \pm 0.03^{1, a^{* *}, b^{* *}, c}$ & $1.62 \pm 0.05^{1 * *, a^{* *}, b^{* *}, c}$ \\
\hline 4. & $\begin{array}{l}15 \text { day after } \\
\text { parturition }\end{array}$ & $1.19 \pm 0.07^{1, \mathrm{a}^{*}, \mathrm{~b}^{* *}, \mathrm{c}^{* *}, \mathrm{~d}}$ & $1.13 \pm 0.03^{1, a^{* *}, b^{* *}, c^{* *}, \mathrm{~d}}$ & $1.77 \pm 0.11^{1, \mathrm{a}, \mathrm{b}, \mathrm{c}, \mathrm{d}}$ \\
\hline 5. & $\begin{array}{l}30 \text { day after } \\
\text { parturition }\end{array}$ & $1.23 \pm 0.06^{1, \mathrm{a}^{*}, \mathrm{~b}^{* *}, \mathrm{c}^{* *}, \mathrm{~d}^{* *}}$ & $0.82 \pm 0.03^{1 * *, a^{* *}, b^{* *}, c^{* *}, \mathrm{~d}^{* *}}$ & $1.99 \pm 0.10^{1, \mathrm{a}^{* *}, \mathrm{~b}^{* *}, \mathrm{c}^{* * *}, \mathrm{~d}^{* *}}$ \\
\hline
\end{tabular}

Means bearing same numerical superscript within a column did not differ significantly $(\mathrm{P} \leq 0.05)$.

Means having same alphabetical superscript within a column did not differ significantly $(\mathrm{P} \leq 0.05)$

from each other for Group-II. *=significant $(\mathrm{P}<0.05)$ and $* *=$ significant $(\mathrm{P}<0.01)$

\section{Periparturient group}

Present study revealed that the plasma iron was significantly lower on the day of parturition as compared to different days of intervals during pre and post parturient period. Moreover, highly significant differences $(\mathrm{p}<0.01)$ for iron concentration were observed between all periparturient groups except between 30 day prepartum with 15 days postpartum, 15 day prepartum with 15 days postpartum and on the day of parturition with 15 days postpartum differences were non-significant.

Similar results were observed by Jacob et al., (2003) and Ram Pravesh (2006). Pankajkumar and Sharma (2005) found adequate level of iron in pregnant cattle of specific area. Asif et al., (1996) found non- significant difference for Fe level. Mehere et al., (2002) found almost same values of serum iron levels from day of calving till 4 weeks postpartum. The serum iron levels did not show significant variation among the weeks.

Iron is the most abundant trace element in the body. Iron is a cellular antioxidant and prevents peroxidative damage (Powell, 2000). The decreased level of iron during pregnancy and on the day of parturition might be due to erythropoesis of the fetus. However increasing values of this element after parturition may be partly due to their binding with the protein and poor excretion along with milk (Kumar et al., 2000).

\section{References}

Agrawal A., Gupta S., Sharma R.K., (2005). 
Role of oxidative stress in female reproduction. Reproductive Biology and Endocrinology. 3: 28.

Akhtar M. S., Farooq A. A. and Mushtaq M. (2009). Serum concentrations of copper, iron, zinc and selenium in cyclic and anoestrus Nili-Ravi buffaloes kept under farm conditions. Pakistan Vet. J. 29(1): 47-48.

Asif, M. M., Zia-ur-rahman, M., Arif, I., Haq U., Javed I. (1996). Trace element and electrolyte concentrations in different physiological states of sahiwal cattle. Journal of Islamic Academy of Sciences. 9(4): 125-128.

Cahit Kalkan, Bayram Yilmaz, Yusuf Turkoz, Erdal Kaygusuzoglu, Hayrettin Cetin, Huseyin Deveci, Ali Mukremin and Halis Ocal (1999). Evaluation of serum and plasma $\mathrm{zn}$ and $\mathrm{cu}$ concentrations with respect to pregnancy during 21 days following insemination in cows. f.U. Saglik Bil. Dergisi, 13 (3): 367-372.

Devraj, M. (1982). Blood serum profiles in calves and post-partum buffaloes (Surti breed) with associated peridata to reproductive efficiency. $\mathrm{phD}$. Thesis, Gujarat Agricultural University, Anand.

Dhami A.J., Patel P.M., Lakum P.D., Ramani V.P. and Pande M.B. (2003). Micronutrient profile of blood plasma in relation to age reproduction status of Holstein Friesian Cattle. Indian J. of Anim. Nurtition. 20 (2): 206-211.

Dufty J.H., Bingley J. B., Cove L. Y. (1977). The plasma zinc concentration of nonpregnant and parturient Hereford cattle. Aust. vet. J. 53: 519-522.

Gitto Eloisa, Russel J. Reiter, Malgorzata Karbownik, Dun-xian Tan, Placido Gitto, Salvatore Barberi, Ignazio Barberi (2002). Causes of Oxidative Stress in the Pre- and Perinatal Period. Biol Neonate. 81: 146-157.
Goff JP. and Stabel JR (1990) Decreased plasma retinol, $\alpha$-tocopherol, and $\mathrm{Zn}$ concentration during the periparturient period: effect of milk fever. J. Dairy Sci. 73: 3195-3199.

Jacob Shibuk, Philomina P.T. and Ramnath, V. (2003). Influence of gestation and early lactation on serum levels of iron, copper and zinc in cross bred heifers. Indian J. Anim. Sci. 46:245-248.

Kleczkowski M., Klucinski W., Sitarska E., Sikora J., Kasztelan R. (2003).Influence of mineral nutrition on superoxide dismutase activity in blood of cows. Bull Vet Inst Pulawy, 47: 547-554.

Kumar R., Sharma I.J. and Agrawal R.G. (2000). Periparturient levels of certain organic and inorganic components in the blood of cows and buffaloes. Indian J. Anim. Reprod., 21(2): 117120.

Meglia GE, Holtenius K, Petersson L, Ohagen P, Persson Waller K (2004). Prediction of vitamin A, vitamin E, selenium and zinc status of periparturient dairy cows using blood sampling during the mid-dry period. Acta vet. scand. 45:119-128.

Meglia GE, Johannisson A, Petersson L, Persson Waller K. (2001).Changes in some blood micronutrients, leukocyte and neutrophil expression of adhesion molecules in periparturient dairy cows. Acta Vet. Scand., 42: 109-120.

Mehere Y.S., Talvelkar B.A., Deshmukh B.T., Nagvekar A.S., and Ingole S.D., (2002). Haematological and trace elements profile during periparturient period in crossbred cows. Indian J. Anim. Sci. 72(2): 148-150.

Michiels, C., M. Raes, O. Toussaint, and J. Remacle. (1994). Importance of Seglutathione peroxidase, catalase, and $\mathrm{Cu} / \mathrm{Zn}-\mathrm{SOD}$ for cell survival against oxidative stress. Free Radic. Biol. 
Med. 17: 235-248.

Muehlenbein, E. L., D. R. Brink, G. H. Deutscher, M. P. Carlson, and A. B. Johnson. (2001). Effects of inorganic and organic copper supplemented to first-calf cows on cow reproduction and calf health and performance. $J$. Anim. Sci. 79:1650-1659.

Oser, B. L. (1979). Hawks physiological chemistry. 14 ${ }^{\text {th }}$ Edn., Mc Grew Hill Books Co. Bombay.

Pankajkumar and Sharma M.C. (2005). Status of micro minerals, Hormones and vitamins in pregnant cattle of Uttarpradesh. Indian Vet. J., 83: 858861.

Pavlata, L.; Podhorsky, A.; Pechova, A.; Chomat, P. (2005). Differences in the occurrence of selenium, copper and zinc deficiencies in dairy cows, calves, heifers and bulls. Veterinarni Medicina. 50(9): 390-400.

Powell S.R. (2000). The antioxidant properties of zinc. Journal of Nutr. 130(5S): 1447S-1454S.

Ram Pravesh Ram (2006). Studies on certain Biochemical and hormonal profiles in plasma pertained to pregnant and postpartum Kankrej cows. M.V.Sc. Thesis, Sardarkrushinagar Dantiwada Agricultural University, Sardarkrushinagar.

Setia, M.S.; Duggal,R.S.; Rajwinder Singh and Rajvir Singh (1994). Distribution of trace elements in whole blood and blood plasma during late pregnancy and different stages of lactation in buffaloes and cows. Buffalo J. 10:213220.

Snedecor, G. W. and Cochran, W. G. (1994). Statistical methods. $8^{\text {th }}$ edn. Oxford and IBH publishing Co, New delhi, India.

Spears, JW., Harvey, RW., Brown, TT., (1991). Effects of zinc methionine and zinc oxide on performance, blood characteristics, and antibody titre response to viral vaccination in stressed feeder calves. JAVMA. 199: 1731-1733.

Toyokuni, S. (1999). Reactive oxygen species-induced molecular damage and its application in pathology. Pathol. Int. 49:91-102.

Weiss WP. (2002). Relationship of mineral and vitamin supplementation with mastitis and milk quality. In: Proc. Annual Meeting, National Mastitis Council, Orlando, Florida, USA, Pp: 37-44.

Xin Z, Waterman DF, Hemken RW, Harmon RJ., (1993). Copper status and requirement during the dry period and early lactation in multiparous Holstein cows. J. Dairy Sci. 76: 2711-2716.

\section{How to cite this article:}

Jinnal Patel, Sandhya S. Chaudhary, Abid Dadawala and Vishal Patel. 2020. Assessment of Oxidative Stress by Trace Elements in Pregnant Kankrej Cows. Int.J.Curr.Microbiol.App.Sci. 9(03): 2464-2471. doi: https://doi.org/10.20546/ijcmas.2020.903.282 